\title{
Directions for preservation and popularization of cultural heritage objects of Crimea peninsula
}

\author{
Victoriia Zhivitsa ${ }^{1, *}$, Victoriia Sidorova ${ }^{1}$, and Dmitry Mosyakin ${ }^{1}$ \\ ${ }^{1}$ Crimean Federal University named after V.I. Vernadsky, Simferopol, Republic of Crimea, Russia
}

\begin{abstract}
Everyone is obliged to take care of the preservation of historical and cultural heritage, to preserve historical and cultural monuments" (Article 44 of the Constitution of the Russian Federation). The study is aimed at considering the most promising methods of safekeeping, maintenance, popularization and museum presentation of cultural heritage. When working on the study, the methods of theoretical analysis and synthesis and the analogy method were used. The authors have identified and analyzed applied areas of safekeeping, maintenance, popularization and modern use of cultural heritage objects, namely: monuments of archeology, architecture and urban planning. Various techniques for inclusion of such objects in the modern socio-cultural and architectural-urban context were analysed. Criteria are selected for choosing monuments of architecture, urban planning and archeology for museification, as well as for their introduction into the tourist and recreational infrastructure of the region. Also the scenario of attracting the population, in particular youth, to the problem of preservation of cultural heritage objects is considered. The authors propose improvement of territory and construction of modular youth centers, and organization of cultural and entertainment events (festivals, exhibitions, historical quests, thematic fairs, performances) near or in the territory of the monument protection zones.
\end{abstract}

\section{Introduction}

On the territory of the Crimeanpeninsula there are 4582 objects of cultural heritage (hereinafter referred to as $\mathrm{CHO}$ ) of federal, regional significance and identified objects of cultural and archaeological heritage (as of December 5, 2019, the register of CHO in the Republic of Crimea and the city of Sevastopol, see https: // gkokn. rk.gov.ru/ru/structure/321). For their further safekeeping and integration into modern life, complex effective measures are required for their maintenance, adaptation and popularization. Currently, it is relevant to determine the strategically correct direction of the program for integration of cultural heritage objects into architectural and urban planning environment.

\footnotetext{
*Corresponding author: vzhivisa@mail.ru
} 


\section{Materials and methods}

As a subject of research, the directions of safekeeping, popularization and exploitation of cultural heritage objects are considered. The theoretical and practical materials concerning the reconstruction of the modern city, the prospects and features of functional use, the inclusion of cultural heritage objects in the modern architectural and urban planning environment are analyzed and streamlined. When working on the study, the methods of theoretical analysis and synthesis and the method of analogy are applied.

Analysis of publications. Works of a general nature include works affecting the problems of ruined monuments, their safekeeping, protection and exhibiting: A.M. Beda, M.M. Boguslavsky, A.A. Voronova, M.F. Denisova, A.N. Domrina, V.Yu. Dukelsky, Yu.N. Zhukova, I.A. Ignatkina, A.B. Kamenets, A.M. Kulemzina, M.E. Kuleshova, N.F. Fedoseeva, I.G. Svichkar, S.M. Shestova.

Fundamental study on safekeeping of cultural property is presented in a book by Professor M. Boguslavsky "International Protection of Cultural Property".

The works relating to the technical side of safekeeping, restoration and museumification of archaeological sites include the works of such authors as: N.L. Kucherevskaya and A.B. Subbotin.

The architectural and urban features of the inclusion of archaeological sites in the modern urban environment are reflected in the works of O.A. Artyufeeva, P.D. Bush, G.V. Esaulova, S.G. Malysheva, M.M. Osipova et al.

An analysis of existing forms of safekeeping and exhibiting of archaeological sites based on domestic and foreign experience is considered in the dissertation by $\mathrm{O}$. Antyuyeva. The author formulated principles and typological classification of archaeological sites included in the space of the Northern branch of the Great Silk Road, for inclusion in the inter-regional extended architectural and spatial exposition.

S.G. Malysheva devoted a Ph.D. thesis to the development of a methodology and determination of the principles of the most complete active inclusion of archaeological heritage lands in modern social functioning based on urban planning and architectural and landscape principles.

In the articles of O.V. Reznik, I.F. Stelmakh, A.V. Shvetsova there are considered the issues of safekeeping and popularization of cultural heritage as a direction of activity of the museums of Crimea.

Based on the analysis of the above mentioned scientific works, the following conclusions are formulated: the problems we have chosen are relevant and are being studied by many researchers; analysis of the theoretical base allows us to conclude that the issues of safekeeping of the $\mathrm{CHO}$, including archaeological sites, have been developed in sufficient detail in both domestic and foreign science; but various aspects of inclusion of these monuments in modern life, as well as the methodology for implementation of museumification from the point of view of architecture and urban planning, are not fully developed; The implementation of safekeeping, museumification work at cultural heritage objects is carried out mainly by specialists in museological, historical and archaeological areas.

There is also a need to refine the classification system and selection criteria for cultural heritage objects for museumification, since all works on this topic are currently focused on the characterization of individual monuments. Cultural heritage objects are not considered comprehensively as links in a single tourist-excursion chain.

\section{Results and discussion}

Immovable historical and cultural monuments form an important part of the national 
cultural heritage of the Russian Federation.

Many settlements of the Republic of Crimea were founded in the ancient period (IIV century BC - III century AD) by Greek colonists, Scythians, Roman military garrisons and other peoples. In the process of development of each locality, its structure was constantly transformed and developed. Currently, the remains of ancient structures are located directly in urban areas, adjacent to residential areas and infrastructure, or are under them. Despite the significant cultural, historical, architectural, urban, tourist interest, for a number of reasons, most of the objects of cultural heritage are not included in the modern life of the city. In this regard, an urgent task needs to be solved, we need to preserve and popularize the archaeological, architectural, cultural heritage with the aim of use in the modern life of society. The solution to the problem will provide multilateral results: popularization of $\mathrm{CHO}$ in the Russian Federation and beyond; involvement of the population of different age groups in cultural events based on monuments of architecture, archeology and history; attracting investors, multi-channel financing of restoration processes and more.

The general classification of $\mathrm{CHO}$ considered in this study is presented in Table 1.

Table 1. Classification of cultural heritage objects.

\begin{tabular}{|c|c|}
\hline \multicolumn{2}{|r|}{ Cultural Heritage Objects } \\
\hline Types of CHO & $\begin{array}{l}\text { Monuments of archeology, architecture, urban planning, landscape } \\
\text { gardening. }\end{array}$ \\
\hline \multicolumn{2}{|r|}{ Classification } \\
\hline Monuments & $\begin{array}{l}\text { - individual buildings, buildings and structures with historically developed } \\
\text { territories (including religious monuments); } \\
\text { - memorial apartments; } \\
\text { - mausoleums, separate burials; } \\
\text { - works of monumental art; } \\
\text { - objects of science and technology, including military. }\end{array}$ \\
\hline $\begin{array}{l}\text { Archaeological } \\
\text { heritage sites }\end{array}$ & $\begin{array}{l}\text { partially or completely hidden in the ground or under water traces of human } \\
\text { existence; cultural layers, places of religious ceremonies (including all } \\
\text { movable objects related to them, the main or one of the main sources of } \\
\text { information about which are archaeological excavations or finds. }\end{array}$ \\
\hline Ensembles & $\begin{array}{l}\text { groups of isolated or united monuments, buildings and structures of } \\
\text { fortification, palace, residential, public, administrative, commercial, } \\
\text { industrial, scientific, educational purposes, as well as religious monuments } \\
\text { and structures, including fragments of historical plans and buildings, clearly } \\
\text { localized in historically developed territories which can be attributed to } \\
\text { urban ensembles. }\end{array}$ \\
\hline $\begin{array}{c}\text { Works of } \\
\text { architecture and } \\
\text { landscape art }\end{array}$ & $\begin{array}{l}\text { fragments of natural landscape, transformed by humans, containing a } \\
\text { complex of elements of improvement, planning, landscaping, small-scale } \\
\text { architecture, hydraulic engineering and other structures and being a one- } \\
\text { time or evolutionary formation (gardens, parks, squares, boulevards, etc.). }\end{array}$ \\
\hline Places of interest & $\begin{array}{l}\text { creations created by man, or joint creations of man and nature, including the } \\
\text { place of existence of folk art crafts; centers of historical settlements or } \\
\text { fragments of urban planning and development; memorials, cultural and } \\
\text { natural landscapes associated with the history of the formation of peoples } \\
\text { and other ethnic communities in the Russian Federation, historical } \\
\text { (including military) events, the lives of prominent historical figures; } \\
\text { archaeological heritage sites; places of worship; burial places of victims of } \\
\text { mass repressions; religious and historical places. }\end{array}$ \\
\hline
\end{tabular}

Many $\mathrm{CHO}$ are characterized by the simultaneous manifestation of many natural and anthropogenic factors that mutually reinforce each other. As a result, the inevitable gradual loss of artistic merit and historical identity of cultural heritage objects occurs. Negative 
processes in the field of cultural heritage in the Republic of Crimea are also associated with transitional processes in the political, legal and organizational spheres, starting in 2014. As a result, interdepartmental disunity, inconsistency of actions of federal and regional authorities and local self-government are still observed.

$\mathrm{CHO}$ are important components of the urban environment and are subject to mandatory risk protection. In this regard, the process of destruction should be opposed by an active state policy at all territorial levels for the consistent reduction of factors threatening the preservation of cultural heritage.

We highlight following priority areas for the protection of cultural heritage from the negative consequences of the manifestation of risk factors:

- development and approval of security zone projects;

- coordination of all types of work on lands of historical and cultural purpose;

- control over the conduct of new construction;

- insurance of monuments;

- withdrawal of environmentally harmful industries from the territories of monuments and from lands of historical and cultural purpose;

- emergency response, safekeeping, restoration, repair;

- carrying out engineering and environmental measures (protection against vibration, stray currents, greening transport schemes of cities, lowering groundwater levels, installing storm sewers, vertical planning and landscaping of historical territories, shore protection works);

- adjustment in the present and future development of industrial production, taking into account safekeeping of cultural heritage;

- popularization of culture in society;

- monitoring the state of cultural heritage objects;

- formation of state policy to consistently reduce negative anthropogenic impacts on the $\mathrm{CHO}$;

- creation of an all-Russian information base and a special advisory service on the protection of $\mathrm{CHO}$ from the undesirable consequences of urbanization, industrialization, transformation of natural complexes, unregulated use of $\mathrm{CHO}$ in the tourism sector.

Currently, an active inventory and inclusion of cultural heritage objects in the unified state register is underway in Crimea, with each monument being assigned a unique number. Design documentation for the $\mathrm{CHO}$ is being developed: security objects, security zones are established, etc.

The current direction for safekeeping of $\mathrm{CHO}$ is urban health monitoring. This is a system for monitoring the state of the urban environment, including tracking the safekeeping of ensembles of the historical part of the city, historical and cultural monuments (Tabl. 2). 
Table 2. System of urban monitoring of the state protected cultural heritage.

\begin{tabular}{|c|c|}
\hline \multicolumn{2}{|c|}{ URBAN MONITORING REGARDING THE CULTURAL HERITAGE OBJECTS } \\
(ARCHEOLOGICAL MONUMENTS)
\end{tabular}

There are three components of urban health care for $\mathrm{CHO}$ :

- prediction of possible impact;

- exposure planning;

- exposure.

Strategic objectives of the state:

1. Safekeeping of cultural heritage objects - repair and restoration works aimed at ensuring the physical safety of the $\mathrm{CHO}$, including safekeeping of the $\mathrm{CHO}$, monument repair, restoration of the monument or ensemble, adaptation, as well as research, survey, design and production work, scientific and methodological guidance, technical and field supervision.

2. The use of objects of cultural heritage means the operation of the $\mathrm{CHO}$ without changing their features in order to develop science, education and culture, patriotic, ideological, moral and aesthetic education of the population, as well as for economic and other purposes, if this does not damage the safety of the $\mathrm{CHO}$ and does not violate their historical -Art value.

3. Popularization of objects of cultural heritage means dissemination of knowledge and information about $\mathrm{CHO}$, provision of public access, publication of information and data on 
cultural heritage objects, including through digital, electronic networks, media, books, newspapers, magazines, other media, through television and radio.

4. The main methods of integrating monuments into the life of a modern city and introducing them into economic circulation used in the world: privatization; development of cultural and educational tourism; creation of products and brands demanded by tourists on the basis of cultural heritage objects. Also, it should be noted that new real estate has a deliberately high price if it is located in a well-maintained historical area with an abundance of restored architectural monuments.

As a result of the analysis and generalization of global trends in the integration of cultural heritage objects into the socio-cultural life of society and into the architectural and urban planning context of a settlement, we single out the most promising ones:

1. Use of the building (architectural monument, history) without changing the function (for example, housing on a 19th-century estate).

2. Use of the building with a replacement function, for example, the placement of public enterprises (banks, offices, hotels, etc.), cultural and educational purposes (museums, art workshops, libraries, etc.).

3. The use of $\mathrm{CHO}$ in research and educational activities. For example, development of a volunteer archaeological movement, visiting archaeological sites by students, organization of participation in excavations, including as part of an international exchange, "living archeology".

4. Museumification, which means, for example, placement of museum expositions in buildings of the XIX-XX centuries. Also, the monument itself can be a museum exhibit, for example, a ruined archeology monument of the ancient or medieval periods.

5. Inclusion of cultural heritage / archaeological sites in the tourist and recreational system of the region.

6. Historical reconstruction - a recreation of the culture of a certain historical era and region based on the object of cultural heritage.

7. Various thematic festivals held in buildings and on the territory of the CHO (historical, photo, retro, wine, cheese, art, youth, painting, crafts, poetic, architectural, student, volunteer, music, fashion and others).

8. Creation of a permanent ethnographic environment in the territory of a place of interest, ensemble or complex of CHO (ethno-street, village, settlement, etc.).

9. Conducting cultural, educational, entertaining events and even commercial events in the territory or with the participation of $\mathrm{CHO}$ as a part of creative tasks (quests, competitions, master classes, fairs, etc.).

10. Creation of conditions for holding non-ongoing public events in the nearby territory of the $\mathrm{CHO}$ in order to popularize and attract the attention of various categories and population groups to historical sites.

Let's consider some of these techniques.

Museumification. With regard to museumification of cultural heritage objects, following theoretical and methodological points are important:

- scientific and cultural value of museumification should be recognized and accepted in the public environment and by the state authorities for the protection of monuments;

- museumification should be based on the perception of historical heritage as a result of interaction of ancient culture and natural environment in the process of developing a certain territory, i.e. as a part of a cultural landscape;

- museumification should be considered as a holistic system of measures for identification, study, restoration and museum display of cultural heritage objects in need of state protection;

- unified concept should be developed for museumification of objects of cultural heritage of the region based on its identity, great cultural and territorial diversity, 
availability of necessary resources to create a system of museum objects in the framework of existing museum complexes and historical and cultural (archaeological) territories.

Due to the considerable ruined state, archeological monuments of the ancient and medieval periods can be used exclusively as objects of research and museum display.

Criteria for selection of objects of archaeological heritage for museumification: historical significance; preservation of the monument (object); informational content; availability; contemporary significance.

Thus, for a successful museum adaptation of an archaeological site, it is necessary to take into account its historical development, conservation status, degree of preservation, dimensional and spatial characteristics, building materials, presence of several periods of development of an architectural and urban planning object, as well as cultural, historical, memorial, aesthetic, artistic, material, historical-scientific and functional-cognitive value.

Currently, three most popular methods of museum conservation at the ruined city archeology sites of the ancient and medieval periods include: the cap method (Fig. 1), the natural conservation method (Fig. 2), reconstructive-archaeological prototyping (Fig. 3).

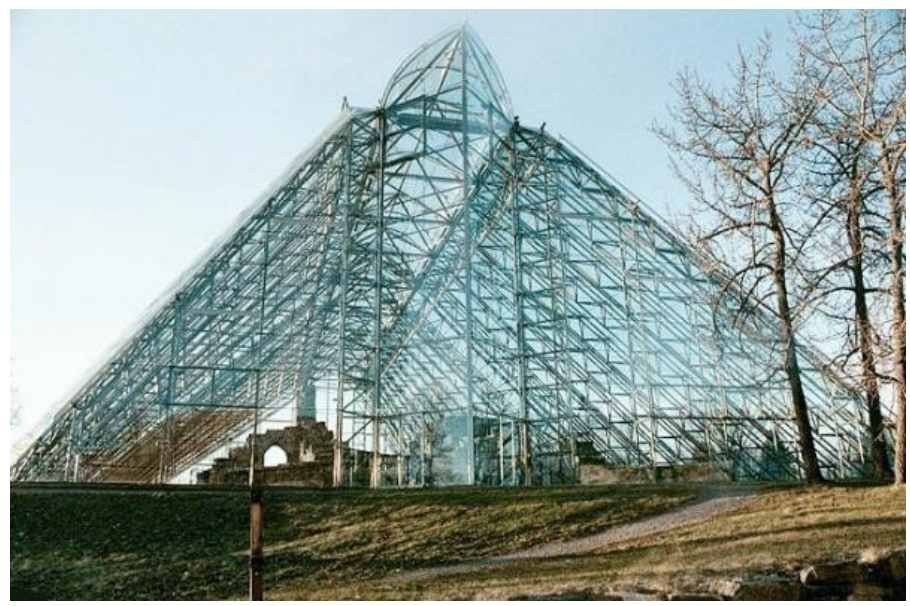

Fig. 1. Hedmark Hamar Museum, Norway.

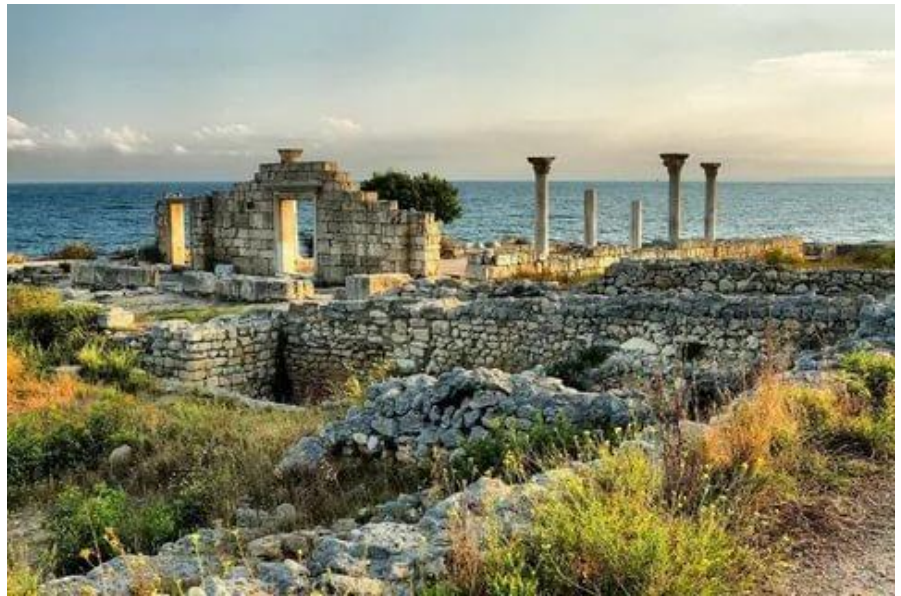

Fig. 2. Historical and archaeological museum-preserve of Tauric Chersonesos. 


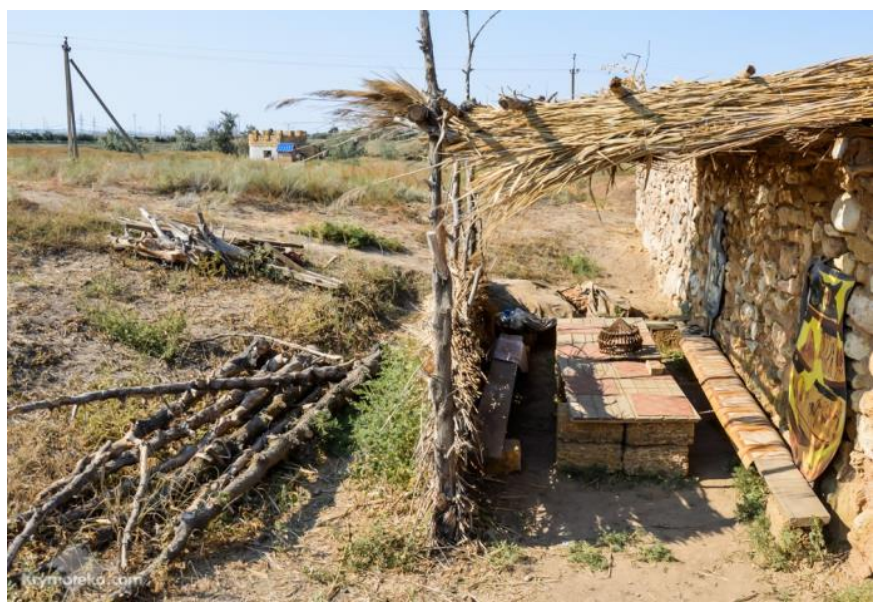

Fig. 3. Greek-Scythian settlement Kara-Tobe. Replica of the Scythian estate.

Due to the unique characteristics of each ancient monument and the set of natural and anthropogenic factors influencing it, it is impossible to unify methods or develop a unified approach to museumification of cultural heritage objects. In each specific case, the composition of the measures depends on how we want to present this architectural, urban or archaeological object to visitors, how we can present and visualize information about it, what measures will ensure the best preservation of the cultural heritage object.

On the basis of well-preserved objects of cultural heritage (buildings and structures, sights, ensembles of the XIX-XX centuries) it is advisable to create museum complexes with the subsequent inclusion in the tourist and recreation system of the region and the country as a whole.

Technologization acts as one of the leading areas of modernization of museums and the most important tool for achieving strategic development goals. The development of computer technology provides new perspectives for archaeological interactive tourism. It is a question of both increasing the entertainment of "standard" expositions (threedimensional reconstruction models, computer animated games for archaeological subjects, virtual excursions), and creating fundamentally new tourist products.

An example of a successful model is the ARCHEOGUIDE (Augmented Reality-based Cultural Heritage On-site Guide) system in Greece. This is a virtual guide providing the construction of augmented reality, three-dimensional images and a mobile computer environment for viewing monuments of history and archeology. Visitors to the museum receive a head-mounted sensor, headphones and mobile computer equipment. The tracking system determines the location of the visitor on the archaeological site. Depending on the established profile and location of the visitor, the corresponding video and audio information is sent to his display and headphones (Fig. 4) (see https://pandia.ru/text/78/053/88545-6.php). 


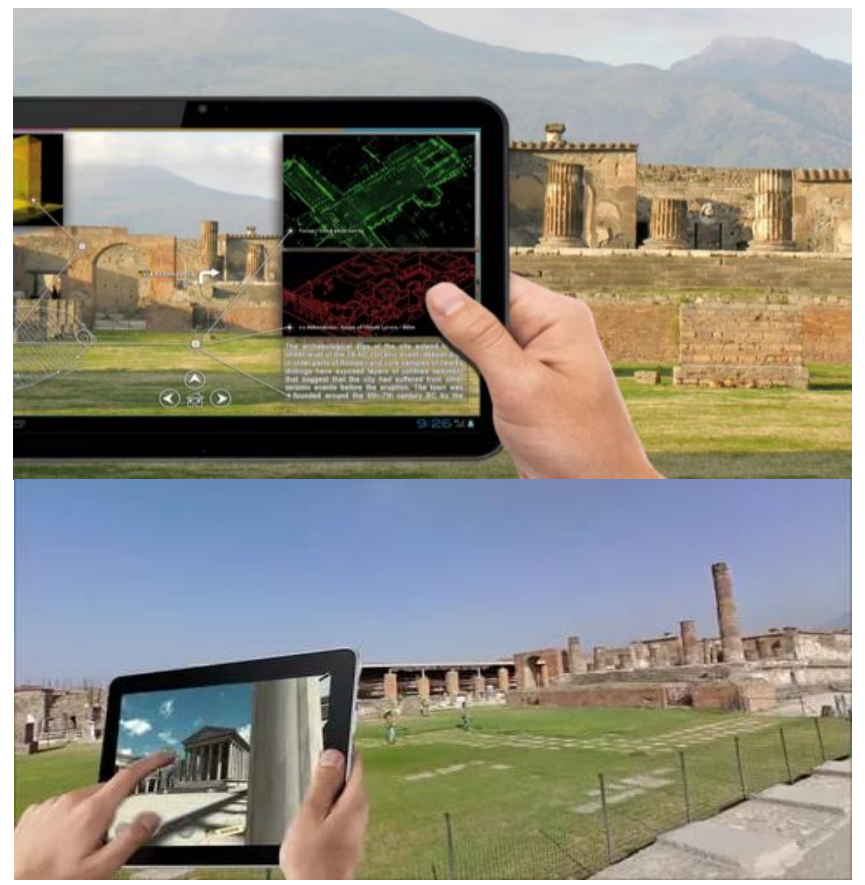

Fig. 4. Virtual tour guide based on the ARCHEOGUIDE system.

It is worth noting that only author's visions, sketch ideas of 3D reconstruction can be offered for ruined architectural structures of the ancient and medieval periods on the basis of archival, natural and archaeological surveys. Since in most cases, even specialists involved in the study of an object for many years cannot accurately describe the architectural and planning and design features of a building or structure due to the lack of the required elements and any reliable data about them. For example, the number of storeys, the location of windows and doorways, the height and parameters of the object and its structural elements (roofs, windows and doorways), architectural details and more.

The experience of 3D modeling was implemented by V. Zhivitsa in documentaries directed by D. Simonenko, with participation of consulting experts involved in the study, preservation and museumification of Crimean archaeological sites Naples Scythian (Simferopol), Mangup Kale (Bakhchisaray), Roman Baths on the South Bank of Crimea (Fig. 5). 


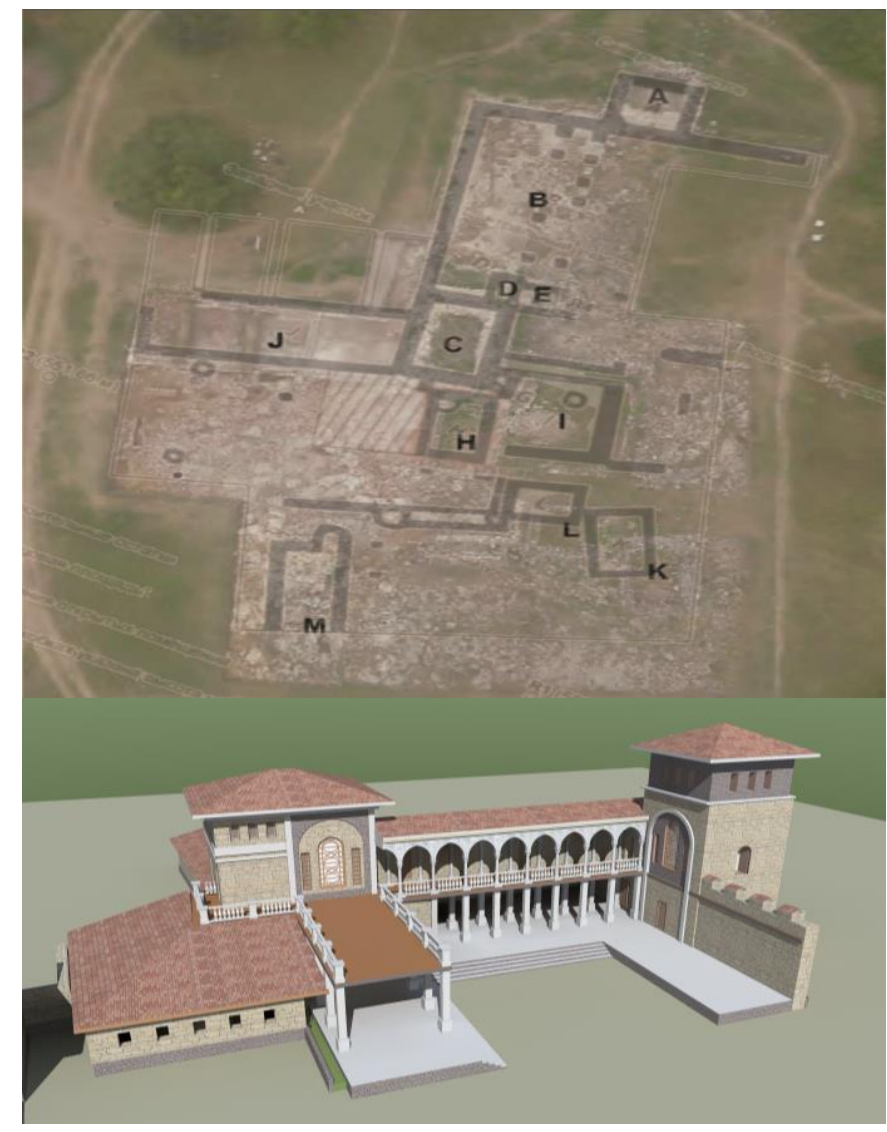

Fig. 5. A variant of the 3D reconstruction of the palace of the Theodoro period on the Mangup Kale plateau. Author: V.V. Zhivitsa, expert consultant: A.G. Herzen for the film "Revival of the Worlds. The Citadel of Theodoro".

3D reconstruction can be scientifically justified for ruined architectural structures of the New time of the 19th-20th centuries, in view of the availability of the necessary amount of design documentation for such objects: plans, facades, sections, photo fixations, sketches, descriptions and so on.

Modern museums of the world widely use the technology of laser scanning of archeology and virtual reality objects for 3D reconstruction of the historical environment of lost objects. However, in Russian Federation this area is only beginning to develop and is applied in isolated cases.

In world practice, cooperation of the cultural sphere and tourist activities is developing successfully. In developed countries, tourism activities support the sphere of culture and stimulate identification and development of its new properties:

1) provides funding for cultural institutions, which are simultaneously objects of tourist infrastructure, and contributes to the implementation of projects in the field of culture;

2) promotes adaptation of cultural goods to the needs and motivations of various categories of tourists, contributing to a fuller use of cultural potential (promoting one's country on the world stage).

The main criteria determining the suitability and attractiveness of $\mathrm{CHO}$ as a tourist attraction include:

- importance of the object as a monument to archeology, architecture, history, nature, etc.; 
- sightseeing value. Unique objects were put in the first place, rare objects took the second place and ordinary objects took the third place;

- natural conditions where the facility is located were considered in terms of the possibility of organizing leisure;

- accessibility, including transport, access to the excursion object, distance from the starting point;

- compact location of objects;

- modern use of the facility;

- safety, improvement of the territory.

The complex task of including $\mathrm{CHO}$ in tourism infrastructure includes solving following issues:

- restoration and preparation of architectural monuments for tourist excursions;

- restoration of parks and historical landscape;

- reconstruction of transport network, taking into account the passage of bulky tourist buses, development of a network of parking lots, organization of transport bypasses of places of tourist concentration;

- creation of pedestrian zones in places of mass visits, increasing the density of service facilities, landscaping, flower decoration, advertising and information saturation of the territory;

- development of public service systems, including medical one;

- adaptation of places of mass visits to the needs of older people and people with disabilities;

- general development of tourist infrastructure facilities.

Despite the fact that the buildings of architectural monuments are more difficult to convert than new ones, they can add a new function that meets the modern needs of the population. Such transformations will be able to breathe a second life into buildings and give them new, missing functions.

A promising type of buildings and structures in modern urban conditions is the universal youth center. It can be stationary and mobile (transformable, modular). It can be created on the basis of the existing $\mathrm{CHO}$ or placed transformable type within the adjacent territories. The main task in creating a youth center as a youth association is: creating a climate that stimulates the growth of cultural and spiritual potential in the field of culture. In our opinion, this type of institution can be used as an additional opportunity to attract attention and form an indifferent team of cultural heritage advocates in our cities. Visiting such a center, everyone will be able to learn something new, bring their own progressive ideas, and also be involved in the process of protecting and popularizing cultural monuments. An important feature of modular youth centers will be their economic benefits, because such centers can have a huge reach of people of different ages, which will attract investment, both private and public.

Formation of such centers will make it possible to achieve in the future following goals: increasing the effectiveness of citywide cultural events; systematic work to restore historical, cultural and moral traditions; development of modern trends in art; variety of socio-cultural infrastructure; involvement of $\mathrm{CHO}$ in the life of the population.

When solving social issues and tasks, and their implementation, it is necessary to use a competent architectural approach. First of all, it is necessary to approach the placement of youth centers in architectural objects - historical monuments. After all, these buildings are not adapted to create easily transformable and dynamic youth spaces although they carry significant cultural and historical value.

Flexibility, modularity, mobility and multifunctionality mean that these should be modern universal youth centers. It is also important to get away from the current fragmentation of functions. Construction of one single center will not exhaust the problem; 
for an effective solution, a whole complex is needed, taking into account the needs and development of various forms of the youth center (freestanding, modular).

When working on this architectural task, one must remember that a culturally and spiritually rich young nation is the key to an educated and healthy society.

Also, in the territory or near the $\mathrm{CHO}$, it is possible to conduct outdoor events (holding various kinds of festivals, exhibitions, quests, thematic fairs and performances) that can involve the population and tourists in the problem of protection, reconstruction, museumification and popularization of architectural and urban planning heritage objects.

\section{Conclusions}

Summing up, it should be noted that it is necessary to develop a common strategy for involving $\mathrm{CHO}$ in the modern life of the region at the level of local authorities in order to achieve maximum effect; outline a plan of specific activities. The issue of preservation and popularization should be considered comprehensively by the authorities. Successful attempts to popularize CHO were made in 2019, for example, the first "School of Heritage Volunteers" in Simferopol. More than 400 people over the age of 18 have been trained. In 2020, the project "Study, Act, Save: Creation of a Monument Preservation Resource Center", proposed by scientists and teachers of the Crimean Federal University, received the support of the Presidential Grants Fund. It is planned to implement a training course on sociocultural design, professional education in the field of preservation of cultural heritage.

In the modern world, cultural heritage as the most important part of modern culture is perceived as an object of consumption, as a result many programs for protection and preservation of monuments need to be processed and carefully planned.

The objects of cultural heritage have enormous potential for development of educational tourism in the Crimea, at the same time, sightseeing visits to cultural heritage objects, archeological sites not prepared for visiting, cause tremendous damage to their condition. The most appropriate and optimal is the development of both integrated and special programs for preservation and museum-tourist use of objects of archaeological heritage at the regional level. Cultural and museum tourism remain undeveloped; there is no program to create a network of historical and cultural territories and museum reserves. Visits and tourist use of the locations of archaeological sites are not regulated. The next stage of our scientific research will include creation of a map-diagram showing cultural heritage objects suitable for introducing ideas for integrating them into cultural events and special events in the territory of Crimea. By the method of experimental design, virtual models of reconstruction and adaptation of some objects of cultural heritage and adjacent territories will be developed.

\section{References}

1. A.M. Beda, V.V. Guchkov, A.N. Zhurov, Cultural heritage protection, 70, Moscow (1996)

2. M.M. Boguslavsky, International protection of cultural property, 192, Moscow (1979)

3. A.A. Voronov, Issues of the theory of reconstruction of architectural monuments, 15, Moscow (1987)

4. M.F. Denisov, Protection of cultural monuments in new urban conditions: to help the lecturer, 42, Society "Knowledge" of Russia, Moscow (1992)

5. A.N. Domrin, V.A. Novinkov, et al., Protection of historical and cultural monuments (Great Britain, Italy, USA, Germany, France), 50, Moscow (1992) 
6. V. Yu. Dukelsky, Museology: Problems of cultural communication in museum activities, 107-116, Moscow (1989)

7. Yu.N. Zhukov, History of the USSR, No. 5, 148-161 (1983)

8. I.A. Ignatkin, Protection of historical and cultural monuments (p. 223, Higher School, Kiev, 1990)

9. A.B. Kamenets, Actual problems of preservation of cultural and natural heritage (p. 95, Institute of Heritage, Moscow, 1995)

10. A.M. Kulemzin, Protection of monuments in Russia as a historical and cultural phenomenon (p. 327, Kemer. reg., Kemerovo, 2001)

11. M.E. Kuleshov, Management of cultural landscapes and other objects of historical and cultural heritage in national parks (p. 45, Publishing House of the Center for the Protection of Wildlife, 2002)

12. N.F. Fedoseev, Historical Heritage of Crimea, No. 22, 189-207 (2008)

13. I.G. Svichkar, Bulletin of Chelyabinsk State University, No. 12 (303), 90-94 (2013)

14. S.M. Shestova, Historical and cultural analysis of regulation of the protection and use of historical and cultural monuments in Russia, 26, Cand. cult. SPb. state un St. Petersburg (2009)

15. M.M. Boguslavsky, International protection of cultural property, 192, Moscow (1979)

16. N.L. Kucherevskaya, Panticapaeum - Bosporus - Kerch - 26 centuries of the ancient capital: international materials. conf. Kerch, 68-70 (2000)

17. A.V. Subbotin, Archaeological Heritage Monitoring and Land Cadastre, 26-30, Institute of Heritage, Moscow (2000)

18. O.A. Artyufeeva, Architectural and urban planning principles for exhibiting archaeological sites of the Great Silk Road in the Lower Volga region, 222, FGBOU VPO MARCHI (2014)

19. O.A. Antyufeeva, Modern Architecture of the World, No. 8, 227-240 (2017)

20. P.D. Bush, Integration of ruined objects of historical heritage into a modern architectural context, 26, Cand. arch. M. (2017)

21. G.V. Esaulov, The architectural and urban heritage of the South of Russia: its formation and cultural potential, 482, D.arch. M. (2004)

22. S.G. Malysheva, Methods of architectural and landscape organization of archaeological heritage lands (on the example of the Samara region), 28, Samara State Academy of Architecture and Civil Engineering (2007)

23. M.M. Osipova, Proceedings of the St. Petersburg State Institute of Culture, 140-146, St. Petersburg (2015)

24. O.A. Artyufeeva, Architectural and urban planning principles for exhibiting archaeological sites of the Great Silk Road in the Lower Volga region, 24, Moscow Architectural Institute (2014)

25. S.G. Malysheva, Methods of architectural and landscape organization of archaeological heritage lands (on the example of the Samara region), 26, Samara State Academy of Architecture and Civil Engineering (2007)

26. O.V. Reznik, I.F. Stelmakh, A.V. Shvetsova, Preservation and popularization of cultural heritage as a line of activity of the museums of Crimea. The cultural heritage of Russia. History and archeology https://cyberleninka.ru/article/n/sohranenie-ipopulyarizatsiya-kulturnogo-naslediya-kak-napravlenie-deyatelnosti-muzeevkryma/viewer (2018) 
27. D. Simonenko, The film "Revival of the worlds. Scythian Palace" https://www.youtube.com/watch?v=MVGpx1U8RY0 (2018)

28. D. Simonenko, The film "Revival of the worlds. Theodoro Citadel" https://www.youtube.com/watch?v=o9j7xfx-Hw0 (2018)

29. D. Simonenko, The film "Revival of the worlds. Roman garrison" https://www.youtube.com/watch?v=BdxLNFcEHso (2018)

30. L.D. Gudkov, B.V. Dubin, N.A. Zorkaya, Youth of Russia, 156-158, Moscow School of Polytechnic Research, Moscow (2011)

31. I.M. Mineeva, Preservation, use and state protection of the archaeological heritage of the South Urals in the second half of the XIX - early XXI centuries, 26, D. East. n Kazan (2011)

32. N.M. Bulatov, Archaeological factor in the planning organization of the territory, 109, Moscow (1997)

33. E.A. Sukhanova, Engineering - from theory to practice: coll. by mater. XXVIII int. scientific-practical conf. No. 11 (24), 7-13, Novosibirsk (2013) 